\title{
Brucella Melitensis invA Gene (BME_RS01060) Transcription Is Promoted Under Acidic Stress Conditions.
}

\section{Raúl Sauceda-Becerra}

Universidad Autónoma de Tamaulipas: Universidad Autonoma de Tamaulipas

\section{Hugo Barrios-García}

Universidad Autónoma de Tamaulipas: Universidad Autonoma de Tamaulipas

Julio Martínez-Burnes

Universidad Autónoma de Tamaulipas: Universidad Autonoma de Tamaulipas

\section{Beatriz Arellano-Reynoso}

Universidad Nacional Autonoma de Mexico

Alejandro Benítez-Guzmán

Universidad Nacional Autonoma de Mexico

\section{Rigoberto Hernández-Castro}

Hospital General Dr Manuel Gea González: Hospital General Dr Manuel Gea Gonzales

Jorge Alva-Pérez ( $\nabla$ jalva@docentes.uat.edu.mx )

Universidad Autónoma de Tamaulipas: Universidad Autonoma de Tamaulipas https://orcid.org/00000002-9320-6387

\section{Research Article}

Keywords: Brucella melitensis, transcription, acidic stress, NUDIX, bacterial adaptation

Posted Date: June 28th, 2021

DOI: https://doi.org/10.21203/rs.3.rs-516691/v1

License: (c) (1) This work is licensed under a Creative Commons Attribution 4.0 International License. Read Full License

Version of Record: A version of this preprint was published at Archives of Microbiology on December 22nd, 2021. See the published version at https://doi.org/10.1007/s00203-021-02664-1. 
Brucella melitensis invA gene (BME_RS01060) transcription is promoted under acidic stress conditions.

Raúl Sauceda-Becerra. Facultad de Medicina Veterinaria y Zootecnia "Dr. Norberto Treviño Zapata". Universidad Autónoma de Tamaulipas. Tamaulipas, México. ORCID:0000-0003-0752-5339

Hugo Barrios-García. Facultad de Medicina Veterinaria y Zootecnia "Dr. Norberto Treviño Zapata". Universidad Autónoma de Tamaulipas. Tamulipas, México. ORCID: 0000-0001-7590-319X

Julio Martínez-Burnes. Facultad de Medicina Veterinaria y Zootecnia "Dr. Norberto Treviño Zapata". Universidad Autónoma de Tamaulipas. Tamaulipas, México. ORCID: 0000-0002-8681-4261

Beatriz Arellano-Reynoso. Departamento de Microbiología e Inmunología. Facultad de Medicina Veterinaria y Zootecnia. Universidad Nacional Autónoma de México Ciudad de México, México. ORCID: 0000-0002$3067-2719$

Alejandro Benítez-Guzmán. Departamento de Microbiología e Inmunología. Facultad de Medicina Veterinaria y Zootecnia. Universidad Nacional Autónoma de México Ciudad de México, México. ORCID: 0000-0003-1671-6401

Rigoberto Hernández-Castro. Departamento de Ecología de Agentes Patógenos. Hospital General "Dr. Manuel Gea González”. Ciudad de México. ORCID: 0000-0002-5656-0942

Jorge Alva-Pérez*. Facultad de Medicina Veterinaria y Zootecnia “Dr. Norberto Treviño Zapata”. Universidad Autónoma de Tamaulipas. Tamaulipas, México. ORCID: 0000-0002-9320-6387 *Corresponding author.

Running Title: Brucella melitensis invA gene transcription

*Facultad de Medicina Veterinaria y Zootecnia "Dr. Noberto Treviño Zapata”. Carretera Victoria-Mante km 5.5 CP. 87000. Ciudad Victoria, Tamaulipas, México. Tel. +528343181800 Ext 2506.

E-mail: jalva@docentes.uat.edu.mx

\section{Acknowledgements}


The authors wish to acknowledge Dr. Rogelio Alejandro Alonso Morales, for his support in the qPCR experiments. This study was funded by Secretaria de Educacion Publica-Consejo Nacional de Ciencia y Tecnología (SEP-CONACYT) in Mexico

\begin{abstract}
The invA gene of Brucella melitensis codes for a NUDIX (nucleoside diphosphate linked to moiety X) hydrolase related to invasiveness. The objective of this work was to evaluate invA transcription under acidic conditions. The invA gene transcription was up regulated at $\mathrm{pH} 3$ and $\mathrm{pH} 5$ observed with semiquantitative real-time PCR in B. melitensis 133 strain. Results indicated that invA gene transcription at $\mathrm{pH} 3$ showed a basal and decreased transcription compared to that of $\mathrm{pH} 5$ incubation. Transcription levels of the dnaK gene were similar to those obtained with invA gene. The survival rates of wild type and invA mutant strains at pH 5 were above $90 \%$ in all post-incubation times. In contrast, at $\mathrm{pH} 3$ there was a time-dependent reduction on both strains at 15 min $(P<$ 0.05). These results suggest that invA gene transcription is promoted under acidic conditions in Brucella melitensis.
\end{abstract}

Keywords Brucella melitensis, transcription, acidic stress, NUDIX, bacterial adaptation. 


\section{Declarations}

\section{Funding}

The present work was funded by SEP-CONACYT Project CB-2014-01-243705 “Análisis de la relevancia de la proteína InvA de Brucella melitensis”

\section{Conflicts of interest/Competing interests.}

On behalf of all authors, the corresponding author states that there is no conflict of interest.

\section{Ethics approval}

Not applicable

\section{Consent to participate.}

Not applicable

\section{Consent for publication}

Not applicable

\section{Availability of data and material}

Data on bacterial survival experiments are in the Additional File 1.xls.

Data on invA and dnaK gene transcriptions analysis are in the Additional File 2.xls

\section{Code availability}

Not applicable

\section{Author's contribution}

RSB: carried out the experiments, interpreted and analyzed data and drafted the manuscript.

HBG: carried out the experiments, made substantial contributions to the work and revised the manuscript critically. 
JMB: made substantial contributions to the work and revised the manuscript critically.

BAR: designed the experiment and revised the manuscript critically.

ABG: designed the experiment and revised the manuscript critically.

RHC: interpreted and analyzed the data and revised the manuscript critically.

JAP: funding obtaining, designed and carried out the experiments, interpreted and analyzed the data and drafted the manuscript.

All authors read and approved the final manuscript. 


\section{Introduction}

Members of the genus Brucella are intracellular pathogens that infect animals and humans, producing reproductive disorders in domestic animals and flu-like symptoms with possible human complications (Olsen et al. 2010). In order to have a successful infection, bacterial pathogens have to overcome iron sequestration, oxidative stress, hyperosmotic conditions, among other stressors (Guan et al. 2017). Acid stress is originated as a defense mechanism against pathogens. Before reaching the intracellular niche, Brucella sp. encounters acid conditions in the host stomach (pH 3.0) if the infection is acquired through the oral mucosa (Sangari et al. 2007). During cell infection, Brucella bacteria are enclosed in a phagosome (called Brucella containing vacuole, BCV) that matures to phagolysosome, with a $\mathrm{pH}$ conditions in the range of 4.5 to 5.0 (Porte et al. 1999). Phagosomelysosome fusion increases the vacuole proton concentration rendering low $\mathrm{pH}$, thereby counteracting intracellular bacteria (Duclos and Desjardins 2000). Not only decreased pH is encountered inside of BCV, but also nutrient deprivation, oxidative environment and lytic enzymes. This harsh environment worsens until bacteria reach the endoplasmic reticulum (ER), where they became replicative. It is speculated that $90 \%$ of Brucella bacterial cells die in this phagosome maturation process, and only $10 \%$ of them survive to become replicative (Celli 2019). Mechanisms of low-pH resistance in Brucella are necessary for full virulence and replication. Different elements have been reported that are associated with the response to acid stress conditions. DnaK protein (Teixeira-Gomes et al. 2000), the response regulator OtpR (Liu et al. 2015), the glutamic acid decarboxylase system (gad operon) in B. microti (Occhialini et al. 2012), the HdeA acid-chaperone (Valderas et al. 2005) among others plays a decisive role in controlling acid stress. Of particular interest is the activation

of the Type IV Secretion System (TIVSS), a principal virulence mechanism that is promoted under intracellular acidic conditions (Boschiroli et al. 2002; Celli et al. 2003; Sieira et al. 2010)

Under these considerations' possible unknown mechanisms of stress resistance or adaptation could interact for Brucella survival. In Brucella melitensis genetic sequence, a possible NUDIX hydrolase gene has been identified, named invA (BME_RS01060). B. melitensis invA mutant strain showed a lower invasion phenotype in non-professional phagocytes and attenuation in the murine model of infection (Alva-Pérez et al. 
2014). In the present work, we demonstrate that the invA gene transcription is promoted under acidic conditions in vitro.

\section{Materials and Methods}

\section{Bacterial strains}

Brucella melitensis 133 (Bm 133) is a biotype 1 Mexican field strain, nalidixic acid-resistant (Hernández-Castro et al. 2000), and B. melitensis invA-km (Bm 133 invA-km) is invA gene mutant strain, kanamycin-resistant (Alva-Pérez et al. 2014). Both strains were maintained on Trypticase Soy Broth or Trypticase Soy Agar (TSA, BD Bacto ${ }^{\mathrm{TM}}$, Sparks Maryland, USA), at $37^{\circ} \mathrm{C}$. For mutant strain, kanamycin (200 $\mu \mathrm{g} / \mathrm{ml}$, Bio Basic Ontario, Canada) was added to TSB or TSA when needed. All bacterial manipulations were done on biosafety level III facilities.

\section{Acid stress survival assay}

Fresh frozen aliquots of $\mathrm{Bm} 133$ and $\mathrm{Bm} 133$ invA-km were thawed at room temperature and seeded in TSA. After $48 \mathrm{~h}$ of incubation at $37^{\circ} \mathrm{C}$, five colony forming units (CFU) were added in $100 \mathrm{ml}$ of TSB and incubated in a shaker at $37^{\circ} \mathrm{C}$ at $200 \mathrm{rpm}$ for $26 \mathrm{~h}$. Bacterial cell concentration (one milliliter of each bacterial strain, $10^{9.7}-10^{10}$, late $\log$ phase) were harvested by $2,000 \mathrm{x} g$ centrifugation for $10 \mathrm{~min}$ at $4^{\circ} \mathrm{C}$. Bacterial cells were re-suspended in $1 \mathrm{ml}$ of acidified medium ( $\mathrm{pH} 5$ or $\mathrm{pH} \mathrm{3,} \mathrm{TSB}$ ) and incubated 5, 10 or 15 min at room temperature (time post-incubation, i.e. pi). $\mathrm{HCl} 2 \mathrm{~N}$ (Sigma-Aldrich, Missouri, USA) achieved the acidified medium added to the required $\mathrm{pH}$. The control group was designed as $1 \mathrm{ml}$ of each strain centrifuged and incubated at the same conditions, but TSB medium was at pH 7.2. After incubations in acidified medium or neutral $\mathrm{pH}$ medium bacterial numbers were calculated by diluting and plating on TSA. Bacterial concentration in neutral $\mathrm{pH}$ medium was determined as $100 \%$ per cent of survival. The experiment was carried out in triplicate, and every experiment had three replicates.

\section{invA gene transcription under acid condition}


The invA gene transcription assay was determined for Bm 133 incubated in acid conditions as described previously. After incubations, bacterial cells were harvested at 2, $000 \mathrm{x} g$ for $1 \mathrm{~min}$ at $4^{\circ} \mathrm{C}$. RNA extraction was done with Tri Reagent (MRC Ohio, USA) following the manufacturer's instructions. Isolated bacterial RNA was re-suspended in $30 \mu \mathrm{l}$ of nuclease-free water (Sigma-Aldrich, Missouri, USA). DNAse I (Invitrogen California, USA) incubation was done following the manufacturer's instructions for DNA elimination. The RNA concentration and purity were determined by spectrophotometer readings (JENWAY Genova, Staffordshire UK). Samples were kept at $-20^{\circ} \mathrm{C}$.

The invA transcription analysis was carried out using a semiquantitative real-time PCR (qPCR) assay. Primers and probes (Table 1) were designed for qPCR with on-line software PrimeQuest of Integrated DNA Technologies (https://www.idtdna.com/Primerquest/Home/Index). 16srRNA gene was used as a housekeeping gene and dnaK gene as acid stress positive control (Teixeira-Gomes et al. 2000). We use the single tube step format, where RNA is transformed into complementary DNA (cDNA), and then PCR is achieved in the reaction. Super Mix RT-PCR 2X (Biotecmol, Mexico City, Mexico) was used. The reaction was integrated of $5 \mu 1$ of retrotranscription PCR buffer $(2 \mathrm{x}), 0.5 \mu \mathrm{M}$ of reverse and forward primer (1 $\mu$ l each, table 1$), 0.5 \mu \mathrm{M}$ of Taqman probe ( $1 \mu \mathrm{l}$, Table 1), $100 \mathrm{ng}$ of RNA sample, and nuclease-free water (up to $10 \mu \mathrm{l}$ ). qPCR protocol was as follows: reverse transcription step at $42{ }^{\circ} \mathrm{C}$ for $30 \mathrm{~min}$, denaturation step at $95{ }^{\circ} \mathrm{C}$ for $10 \mathrm{~min}$, followed for 40 cycles of $95{ }^{\circ} \mathrm{C}$ for $5 \mathrm{sec}$ and $60{ }^{\circ} \mathrm{C}$ for $30 \mathrm{sec}$ qPCR was achieved in Step One thermocycler (Applied Biosystems, California USA). invA gene transcription (relative expression) was calculated by the $2^{-\Delta \Delta \mathrm{Ct}}$ method (Livak and Schmittgen 2001). Experiments were done in triplicate and for every time evaluated, two independent experiments were done. In order to evaluate primer efficiency, different Bm 133 cDNA concentrations were tested for $d n a K$ or invA qPCR amplifications (Livak and Schmittgen 2001). The dnaK gene specific primers resulted in efficient amplification and was similar to that of the amplification of endogenous gene (equation of $d n a K$ gene: $-3.993 x+14.556 ; R^{2}: 0.9899$; equation of $16 s r$ RNA gene: $-4.0748 x+12.677$; $\mathrm{R}^{2}$ : 0.9897). Similarly, the invA gene specific primers resulted in efficient amplification and was similar to that of the amplification of endogenous gene (equation of $i n v A$ gene: $-3.4247 x+11.405 ; \mathrm{R}^{2}$ : 0.9995 ; equation of 16sr RNA gene: $\left.-3.384 x+9.6809 ; \mathrm{R}^{2}: 0.9993\right)$. 
Table 1. Oligonucleotides used in this study

\begin{tabular}{|c|c|c|}
\hline Gene & Primer & Sequence \\
\hline \multirow{4}{*}{ invA } & Foward & 5'-GAGGGCGATGAAAGTGAAATTG-3' \\
\hline & Probe & 5'ACTGCTGAGTTCGATTGCTGGGAA-3' \\
\hline & Reverse & 5'-CGCAACCACCTGTTCATAGA-3' \\
\hline & Foward & 5'-ACCTTCCTCTCGGCTTAT-3' \\
\hline \multirow[t]{3}{*}{ 16sr RNA } & Probe & 5'-CCCTTAGAGGCCCAACTGAATGCT-3' \\
\hline & Reverse & 5'-GTCGTGAGATGTTGGGTTAAGT-3' \\
\hline & Foward & 5'-GACGTGTCGGTTCTGGAAAT-3' \\
\hline \multirow[t]{2}{*}{ dnaK } & Probe & 5'-TGAAGTGAAGTCCACCAATGGCGA-3' \\
\hline & Reverse & $5^{\prime}$-CTTGAACTCGGCAACCAGATA-3' \\
\hline
\end{tabular}

\section{Statistical analysis}

Survival bacterial results and qPCR results were statistical analyzed with two-way ANOVA and mean multiple comparisons were made with Tukey's test. The significance level was set at $P<0.05$ or $P<0.001$. The GraphPad Prism 8 software (GraphPad Software, Inc., La Jolla, CA) was used for analysis and graphics construction.

\section{Results}

\section{Bacterial survival rate under acid stress conditions}

Survival assay results at $\mathrm{pH} 5$ demonstrate no significant differences, except for mutant survival strain comparison, where Bm 133 invA-km survived almost $10 \%$ more at 10 min compared to that of 15 min $(P<$ 0.05, Figure 1a). At 5- and 10-min pi, mutant and wild-type strains had more than $90 \%$ of survival rate, and at 15 min pi, a slight decrease in the invA mutant strain survival rate was observed, compared to that of wild type strain ( $84.6 \pm 4.8$ and $92.7 \pm 4.6$, respectively). Nevertheless, no significant difference was observed. In contrast, survival assay results at $\mathrm{pH} 3$ demonstrate a reduced bacterial survival at 15 min pi (Figure 1b). Bm 133 invA$\mathrm{km}$ survival at 15 min was less compared to that of the same strain at 5 min pi $(62.9 \pm 6.5$ vs $93.8 \pm 3.9, P=$ 
0.009), in the same way, the mutant strain at 15 min pi. survived less than that of the parental strain at 10 min $(62.9 \pm 6.5$ vs $87.4 \pm 4.9, P=0.005)$. Also, wild-type strain at 10 min survived less than that of the mutant strain at $5 \min (87.4 \pm 4.9$ vs $93.8 \pm 3.9, P=0.029)$. Overall tendencies to better bacterial survival were observed at $\mathrm{pH} 5$ than that of $\mathrm{pH} 3$. However, bacterial survival did not decrease to $50 \%$ for both strains, indicating a good resistance to low $\mathrm{pH}$. All the bacterial survival data are given in the Additional File 1.xls

\section{Relative expression of $i n v A$ gene}

Relative transcription results demonstrate different patterns of invA mRNA concentration depending on $\mathrm{pH}$ and time incubation (Figure 2). Under $\mathrm{pH} 5$ conditions maximum invA gene transcription was observed at 15 min pi and compared at 5- and 10-min pi, invA gene transcription was 25.4 and 15.4 times more upregulated, respectively $(P<0.0001$, Fig $2 a)$. In addition, dnaK gene was significantly up-regulated since 10 min pi (above 2 Relative Transcription Units, RTU). In contrast, at $\mathrm{pH} 3$, levels of invA mRNA transcripts were below 1 RTU (maximum level observed at 5 min pi, i.e. $0.79 \pm 0.26$, Fig 2b). Likewise, dnaK gene transcription was below 1 RTU and it was significantly lower than that of invA gene transcription at 5 min pi $(0.46 \pm 0.1$ compared to $0.79 \pm 0.26, P<0.05)$. Levels of mRNA transcripts for both genes beyond 10 min pi were below 0.5 RTU, indicating a constant decrease in transcription. These results demonstrate that a $\mathrm{pH} 5$ invA gene transcription is promoted and is time dependent. In contrast at $\mathrm{pH} 3$ invA gene transcripts remained low at basal levels. All the transcription data and analysis are shown in the Additional File 2.xls

\section{Discussion}

Low $\mathrm{pH}$ reduced nutrient availability and oxidative environment are present during the invasion, at the initial stages of Brucella infection. There are multiple systems to sense and respond to environmental factors that could be detrimental to bacterial cells to survive and multiply. Acid stress is detrimental to bacterial protein structure and function, and cellular bioenergetics (Krulwich et al. 2011). Therefore, Brucella melitensis survival

to acid stress is crucial for a successful intracellular infection (Roop et al. 2009). In the present work we demonstrated survival to two different low $\mathrm{pH}$ conditions. The oral route of Brucella infection is the most common route of infection. Live Brucella counteract the proteolytic and acid environment of the stomach of mammals (pH 1.0 to 3.0). Passage to this acid milieu is fast and transitional (in a calf-ligated ileal loop, Brucella bacteremia is detected in $30 \mathrm{~min}$ ) (Rossetti et al. 2013). Urease activity of Brucella have been related as the 
principal system for stomach low-pH resistance (Sangari et al. 2007). Subsequently, Brucella bacterial cells can disseminate systemically through transepithelial migration or invasion on M cells (Rossetti et al. 2013). Final intracellular infection in epithelial and monocyte-macrophage cells is determinant for the establishment of successful infection. In the initial steps of infection (5 to 15 minutes), traffic through endosome-phagosome with a pH to 4.0 to 5.0 determines the intracellular fate of Brucella (Celli 2019). Brucella transition to low-pH environment could be fast (no more than 30 minutes). Considering these two $\mathrm{pH}$ scenarios, we hypothesized that invA gene transcription could be necessary for the Brucella melitensis acid resistance mechanism. In pH 5, survival of both strains was higher up $80 \%$, still at $\mathrm{pH} 3$ bacterial survival was decreased according to time evaluated, with less survival at 15 min. No differences at the same time evaluated were observed between Bm 133 (wild-type) and Bm 133 invA-km (mutant) strains. Similar results were observed by Cui et al. (2013) at pH 3, where B. melitensis $16 \mathrm{M}$ strain survived less than $40 \%$, and $h f q$ mutant survived $20 \%$. Gene transcription analysis showed that $i n v A$ is progressively upregulated at $\mathrm{pH}$. Conversely, at $\mathrm{pH} 3 \mathrm{invA}$ transcription is basal; nevertheless, invA mRNA transcripts are present, suggesting a constitutive expression under acidic conditions. These results demonstrate that invA gene transcription is up-regulated under acidic stress. Other factors that are up-regulated under acidic conditions ( $\mathrm{pH} 4.4$ ) are two-component response regulator BMEI1329, dnaK and $d n a J$ gene (Liu et al. 2016), the two-component system OtpR (Occhialini et al 2012) and the $v j b R$ gene at a pH of 5.5 (Arocena et al. 2012)

Ttranscriptomic analysis demonstrated that oxidation-reduction, catalytic, and bacterial transport processes are critical in a low $\mathrm{pH}$ environment in virulent B. melitensis (Salmon-Divon et al. 2019). Meanwhile, in B. melitensis Rev1 strain (vaccine strain) metabolism, DNA repair and stress adaptation (i.e., GroEL (BMEII1048) and cold shock proteins (BMEI0498 and BME_RS02600) expression) are essential processes for low pH adaptation (Salmon-Divon and Kornspan 2020). These studies demonstrate that regardless of attenuated or virulent strain studied, the bacterial metabolic process is determinant for acid stress adaptation. In this context, upregulation of the invA gene could promote $B$. melitensis low $\mathrm{pH}$ adaptation through oligophosphate nucleosides hydrolysis (catalysis of potentially toxic compounds). The amino acid analysis demonstrated that the invA gene of B. melitensis has nucleoside hydrolase characteristics. The invA gene preserves the NUDIX box and has $76 \%$ similarity with the invA gene of Rickettsia prowazekii and nudH-ialB locus of Bartonella 
bacilliformis (Alva-Pérez et al. 2014). Further studies are required to demonstrate oligophosphate nucleoside hydrolysis by invA gene of $B$. melitensis and relevance.

$\mathrm{NtrX}$ is a response regulator protein implicated in low oxygen fitting of B. abortus (Carrica et al. 2013). Fernandez and coworkers, demonstrate that phosphorylation of the response regulator (RR) of the NtrX protein occurs only in the acidified medium (Fernández et al. 2018). Furthermore, the NtrY/X two-component system activates denitrification enzymes that consume protons, thereby counteracting low pH (Carrica et al. 2012). Another genetic factor that requires acidification is the virB operon, which encodes the TIVSS in Brucella, considered the principal virulence factor (Ke et al. 2015). These observations indicate that adaptation to low $\mathrm{pH}$ is not only necessary but also a signal for an overall adaptation to intracellular stress conditions (i.e. low oxygen tension). We hypothesize that InvA works together with other factors, as well, for adaptation. It would be of interest to specify how InvA protein contributes to the stress response network of Brucella and clarify the specific time InvA protein is contributing to intracellular pathogenesis. Current experiments are underway to decipher these questions.

Through this study we demonstrate that invA gene is up-regulated under low-pH conditions. At pH 5 invA gene up-regulation was observed according to time, nevertheless at $\mathrm{pH} 3$ up-regulation was almost basal, probably indicating minimal invA gene intervention in low-pH adaptation. Acid stress adaptation for intracellular invasion in Brucella spp. are critical in order to have a successful infection. It has been demonstrated that an invA gene mutant strain was a lower invasion phenotype compared to parental strain. This observation indicates that, under in vitro intracellular infection, invA gene aids to Brucella melitensis invasion. In this work, we demonstrate that low-pH up-regulates invA transcription, probably indicating that the InvA protein is contributing to stress adaptation. 


\section{References}

Alva-Pérez J, Arellano-Reynoso B, Hernández-Castro R, Suárez-Güemes F (2014) The invA gene of Brucella melitensis is involved in intracellular invasion and is required to establish infection in a mouse model.

Virulence. 5:1-12. https://doi.org/10.4161/viru.28589

Arocena GM, Zorreguieta A, Sieira R (2012) Expression of VjbR under nutrient limitation conditions is regulated at the post-transcriptional level by specific acidic $\mathrm{pH}$ values and urocanic acid. PLoS One.

7:e35394. https://doi.org/10.1371/journal.pone.0035394

Boschiroli ML, Ouahrani-Bettache S, Foulongne V, Michaux-Charachon S, Bourg G, Allardet-Servent A, Cazevieille C, Liautard JP, Ramuz M, O’Callaghan D et al (2002) The Brucella suis virB operon is induced intracellularly in macrophages. Proc Natl Acad Sci U S A. 99:1544-1549. https://doi.org/10.1073/pnas.032514299

Carrica MC, Fernandez I, Martí MA, Paris G, Goldbaum FA (2012) The NtrY/X two-component system of Brucella spp. acts as a redox sensor and regulates the expression of nitrogen respiration enzymes. Mol Microbiol. 85:39-50. https://doi.org/10.1111/j.1365-2958.2012.08095.x

Carrica MC, Fernandez I, Sieira R, Paris G, Goldbaum FA (2013) The two-component systems PrrBA and NtrYX co-ordinately regulate the adaptation of Brucella abortus to an oxygen-limited environment. Mol Microbiol. 88:222-233. https://doi.org/10.1111/mmi.12181

Celli J, de Chastellier C, Franchini D-M, Pizarro-Cerda J, Moreno E, Gorvel J-P (2003) Brucella evades macrophage killing via VirB-dependent sustained interactions with the endoplasmic reticulum. J Exp Med. 198:545-556. https://doi.org/10.1084/jem.20030088

Celli J (2019) The Intracellular life cycle of Brucella spp. Microbiol Spectr 7:10.1128/microbiolspec.BAI0006-2019. https://doi.org/10.1128/microbiolspec.BAI-0006-2019

Cui M, Wang T, Xu J, Ke Y, Du X, Yuan X, Wang Z, Gong C, Zhuang Y, Lei S, Su X, Wang X, Huang L, Zhong Z, Peng G, Yuan J, Chen Z, Wang Y (2013) Impact of Hfq on global gene expression and intracellular 
survival in Brucella melitensis. PLoS One. 8:e71933. https://doi.org/10.1371/journal.pone.0071933

Duclos S, Desjardins M (2000) Subversion of a young phagosome: the survival strategies of intracellular pathogens. Cell Microbiol 2:365-377. https://doi.org/10.1046/j.1462-5822.2000.00066.x

Fernández I, Sycz G, Goldbaum FA, Carrica MC (2018) Acidic pH triggers the phosphorylation of the response regulator NtrX in alphaproteobacteria. PLoS One. 13:e0194486.

https://doi.org/10.1371/journal.pone.0194486

Guan N, Li J, Shin H, Du G, Chen J, Liu L (2017) Microbial response to environmental stresses: from fundamental mechanisms to practical applications. Appl Microbiol Biotechnol 101:3991-4008. https://doi.org/10.1007/s00253-017-8264-y

Hernández-Castro R, Verdugo-Rodríguez A, Gutiérrez-Pabello JA, Adams L, Suárez-Güemes F, SahagúnRuiz A (2000) Identification of four genes of the Brucella melitensis ATP synthase operon F0 sector: relationship with the Rhodospirillaceae family. Microb Comp Genomics. 5:163-171. https://doi.org/10.1089/omi.1.2000.5.163

Ke Y, Wang Y, Li W, Chen Z (2015) Type IV secretion system of Brucella spp. and its effectors. Front Cell Infect Microbiol. 5:72. https://doi.org/10.3389/fcimb.2015.00072

Krulwich TA, Sachs G, Padan E (2011) Molecular aspects of bacterial pH sensing and homeostasis. Nat Rev Microbiol. 9:330-343. http://doi.org/10.1038/nrmicro2549

Liu Q, Liu X, Yan F, He Y, Wei J, Zhang Y, Liu L, Sun Y (2016) Comparative transcriptome analysis of Brucella melitensis in an acidic environment: Identification of the two-component response regulator involved in the acid resistance and virulence of Brucella. Microb Pathog 91:92-98.

https://doi.org/10.1016/j.micpath.2015.11.007

Liu W, Dong H, Li J, Ou Q, Lv Y, Wang X, Xiang Z, He Y, Wu Q (2015) RNA-seq reveals the critical role of OtpR in regulating Brucella melitensis metabolism and virulence under acidic stress. Scientific reports. 5:10864. https://doi.org/10.1038/srep10864

Livak KJ, Schmittgen TD (2001) Analysis of relative gene expression data using real-time quantitative PCR 
and the 2(-Delta Delta C(T)) method. Methods. 25:402-408. https://doi.org/10.1006/meth.2001.1262

Occhialini A, Jiménez De Bagüés MP, Saadeh B, Bastianelli D, Hanna N, De Biase D, Köhler S. (2012) The glutamic acid decarboxylase system of the new species Brucella microti contributes to its acid resistance and to oral infection of mice. J Infect Dis. 206:1424-1432. https://doi.org/10.1093/infdis/jis522

Olsen SC, Bellaire BH, Roop II MR, Thoen CO (2010) Brucella. In: Gyles CL, Prescott JF, Songer G, Thoen Charles O (Eds) Pathogenesis of bacterial infections in animals, 4th ed. Ames, Iowa Wiley-Blackwell, p. 429438

Porte F, Liautard JP, Köhler S (1999) Early acidification of phagosomes containing Brucella suis is essential for intracellular survival in murine macrophages. Infect Immun 67:4041-4047.

https://doi.org/10.1128/IAI.67.8.4041-4047.1999

Roop RM, Gaines JM, Anderson ES, Caswell CC, Martin DW (2009) Survival of the fittest: how Brucella strains adapt to their intracellular niche in the host. Med Microbiol Immunol. 198:221-238.

https://doi.org/10.1007/s00430-009-0123-8

Rossetti CA, Drake KL, Siddavatam P, Lawhon SD, Nunes JE, Gull T, Khare S, Everts RE, Lewin HA, Adams LG (2013) Systems biology analysis of Brucella infected Peyer's patch reveals rapid invasion with modest transient perturbations of the host transcriptome. PLoS One. 8:e81719.

https://doi.org/10.1371/journal.pone.0081719

Salmon-Divon M, Zahavi T, Kornspan D (2019) Transcriptomic analysis of the Brucella melitensis rev.1 vaccine strain in an acidic environment: Insights into virulence attenuation. Front Microbiol. 10:250. https://doi.org/10.3389/fmicb.2019.00250

Salmon-Divon M, Kornspan D (2020) Transcriptomic analysis of smooth versus rough Brucella melitensis Rev.1 vaccine strains reveals insights into virulence attenuation. Int J Med Microbiol. 310:151363. https://doi.org/10.1016/j.ijmm.2019.151363 
Sangari FJ, Seoane A, Rodríguez MC, Agüero J, García Lobo JM (2007) Characterization of the urease operon of Brucella abortus and assessment of its role in virulence of the bacterium. Infect Immun 75:774-780. https://doi.org/10.1128/IAI.01244-06

Sieira R, Arocena GM, Bukata L, Comerci DJ, Ugalde RA (2010) Metabolic control of virulence genes in Brucella abortus: HutC coordinates virB expression and the histidine utilization pathway by direct binding to both promoters. J Bacteriol. 192:217-224. https://doi.org/10.1128/JB.01124-09

Teixeira-Gomes AP, Cloeckaert A, Zygmunt MS (2000) Characterization of heat, oxidative, and acid stress responses in Brucella melitensis. Infect Immun. 68:2954-2961. https://doi.org/10.1128/iai.68.5.2954$\underline{2961.2000}$

Valderas MW, Alcantara RB, Baumgartner JE, Bellaire BH, Robertson GT, Ng WL, Richardson JM, Winkler ME, Roop RM (2005) Role of HdeA in acid resistance and virulence in Brucella abortus 2308. Vet Microbiol. 107:307-312. https://doi.org/10.1016/j.vetmic.2005.01.018 


\section{Figures Titles and Legends}

Fig 1. Bacterial survival percentage under acidic conditions of B. melitensis 133 and B. melitensis invA$\mathbf{k m}$. Results are presented as the average of three independent experiments \pm standard deviation. $*: p<0.05 * *$ : $p<0.001$. a) Bacterial survival at $\mathrm{pH} 5$ and b) Bacterial survival at $\mathrm{pH} 3$

Fig 2. Relative invA and $d n a K$ transcription of $B$. melitensis 133 under acidic conditions. Results are presented as the average of two independent experiments \pm standard deviation. RTU: Relative Transcription Units. Different letters are presented as different statistical significance between transcription analyzed. a) Transcription at $\mathrm{pH} 5$ and b) Transcription at $\mathrm{pH} 3$

\section{Supplementary material}

Additional File 1.xls Spreadsheet of bacterial survival. It contains the three representative experiments. Data are in percentages by time, strain and $\mathrm{pH}$ (sheet 1: $\mathrm{pH} 5$, sheet 2: $\mathrm{pH} 3$ )

Additional File 2.xls Spreadsheet of $i n v A$ and $d n a K$ transcription It contains the $\mathrm{Ct}$ (crossing threshold) values of the qPCR of $\operatorname{invA}$, dnaK and $16 s r R N A$ (endogenous control) genes. In addition, it contains the $2^{-\Delta \Delta C t}$ analysis method. Results of every pH analyzed are in different sheets 
Figures

a) $\mathrm{pH} 5$

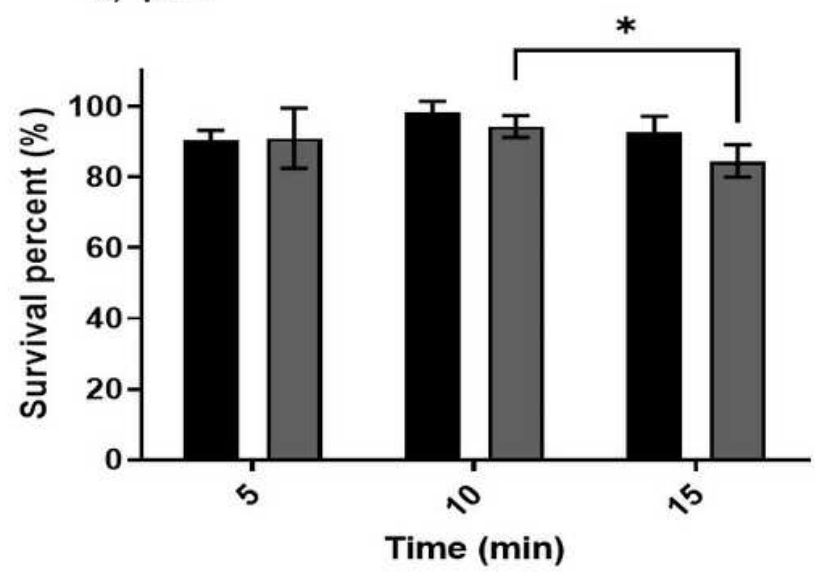

b) $\mathrm{pH} 3$

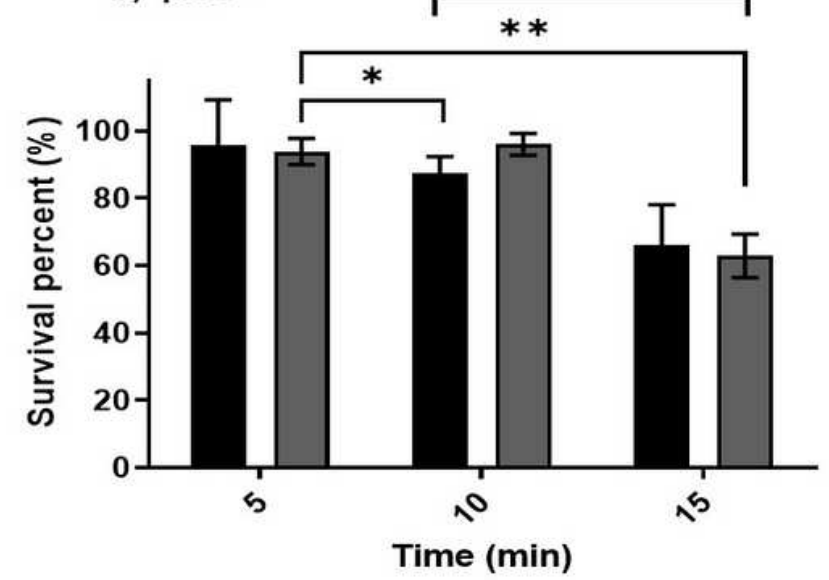

$\mathrm{Bm} 133$

invA-km

\section{Figure 1}

Bacterial survival percentage under acidic conditions of B. melitensis 133 and B. melitensis invA-km. Results are presented as the average of three independent experiments + standard deviation. $*$ : $p<0.05$ **: $\mathrm{p}<0.001$. a) Bacterial survival at $\mathrm{pH} 5$ and b) Bacterial survival at $\mathrm{pH} 3$

a) $\mathrm{pH} 5$

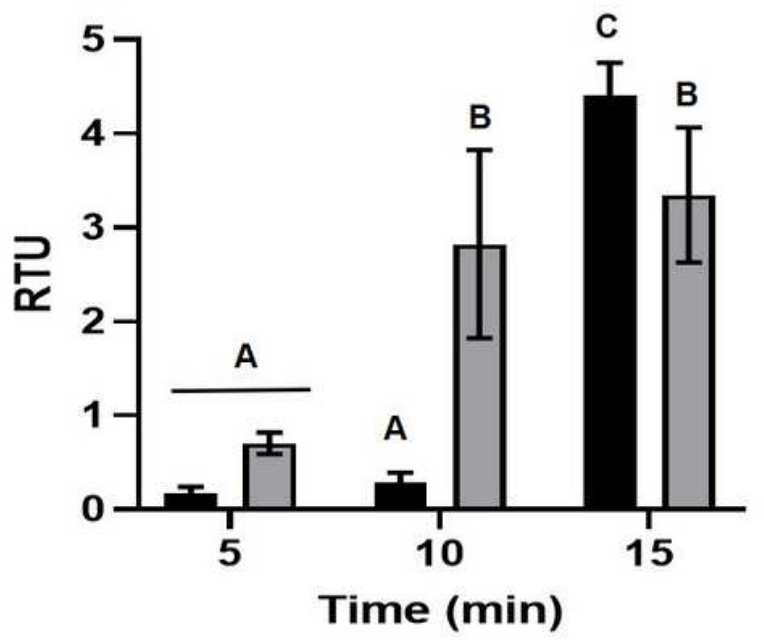

b) $\mathrm{pH} 3$

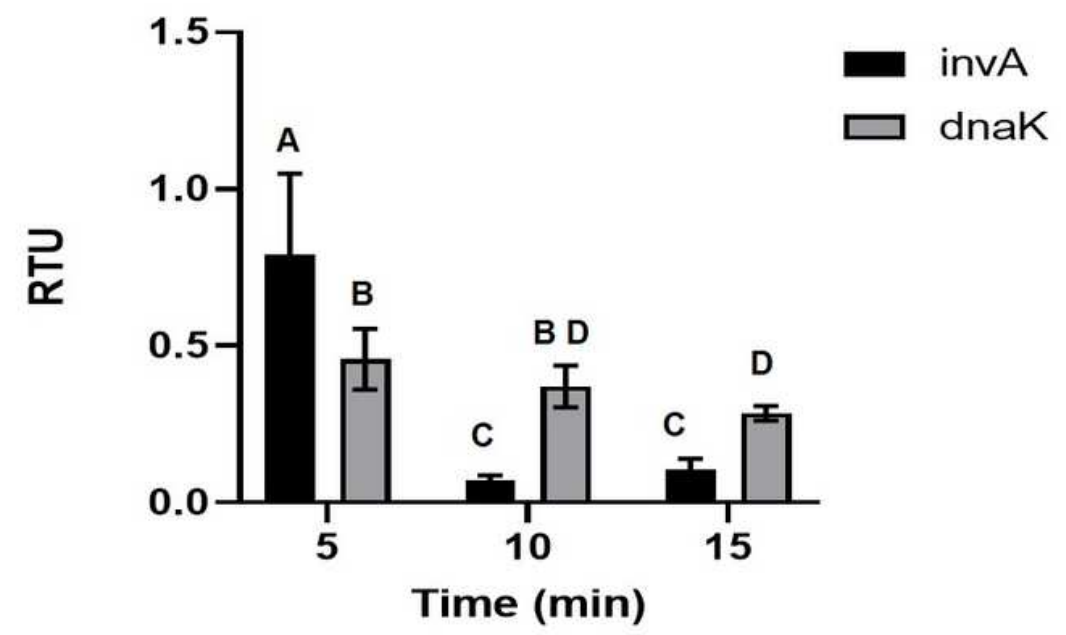

Figure 2

Relative invA and dnaK transcription of B. melitensis 133 under acidic conditions. Results are presented as the average of two independent experiments + standard deviation. RTU: Relative Transcription Units. Different letters are presented as different statistical significance between transcription analyzed. a) Transcription at $\mathrm{pH} 5$ and b) Transcription at $\mathrm{pH} 3$

\section{Supplementary Files}


This is a list of supplementary files associated with this preprint. Click to download.

- AdditionalFile1.xIsx

- AdditionalFile2.xIsx 